\title{
Erzurum Kongre Süreci ve Demokratik Tartışmalar
}

Erzurum Congress Process and Democratic Debates

\section{Prof. Dr. Erdal AYDOĞAN ${ }^{1}$}

Başvuru Tarihi: 17.03 .2020

Kabul Tarihi: 16.04 .2020

Makale Türü: Derleme

Öz

Mondros Mütarekesi sonrası ülkenin içinde bulunduğu kargaşa ve umutsuzluk devleti yönetenleri olduğu kadar sivil hayatı da derinden etkiledi. Bu durum karşısında Anadolu insanınin yaşama arzusu ve heyecan ise her türlü takdirin üzerindeydi. Genelde bütün Anadolu'da özelde ise Erzurum'da bu heyecan yeni oluşumlara zemin hazırlad. Bu durum Mustafa Kemal Paşa'nın Anadolu'ya gönderilmesi, akabinde de Erzurum'a gitmesi ile Mustafa Kemal Paşa merkezli Milli Mücadele'nin de önemli aşamasın oluşturdu. Erzurum Kongresi'nin toplanması ve burada ortaya çıkan gelecek tasavvuru ise bundan sonraki faaliyetlere örnek oldu. Kongrenin toplanması, işleyişi, dil ve uslubu, milli irade ve egemenlik vurgusu ile bundan sonraki faaliyetlere de örnek oldu.

Anahtar Kelimeler: Milli İrade, Milli Mücadele, Seçim, Tüzük, Bağımsızlık

\begin{abstract}
After the Mudros Armistice, the turmoil and despair of the country affected the civil life as well as those who governed the state. In the face of this situation, the desire and excitement of the Anatolian people were above all kinds of appreciation. This excitement paved the way for new formations generally in Anatolia, privately in Erzurum. This situation also constituted the important stage of the Mustafa Kemal Pasha-centered national struggle with Mustafa Kemal Pasha's being sent to Anatolia and subsequently going to Erzurum. The gathering of the Erzurum Congress and the future imagery that emerged here set an example for following activities. The congress's gathering also served as an example with its functioning, language and style for future activities with the emphasis on national will and sovereignty.
\end{abstract}

Keywords: National Will, National Sovereignty, Election, Legislation, Independence

\footnotetext{
${ }^{1}$ Atatürk Üniversitesi Atatürk İlkeleri ve İnkılap Tarihi Enstitüsü, erdalaydogan@atauni.edu.tr, ORCID: 0000-0002-1343-951X
} 


\section{Giriş}

I. Dünya Savaşı'nı büyük kayıplarla bitiren Osmanlı Devleti, 30 Ekim 1918'de Mondros Mütarekesi'ni imzalamak zorunda kaldı. Uluslararası hukukun sınırlarını zorlayan mütareke ahkâmı adeta bir antlaşma hükümleri gibi uygulamaya konuldu. Bu durum karşısında olup bitenleri en başından beri kabullenmiş olan İstanbul hükümetlerinin basiretsiz ve teslimiyetçi tavrı ise dikkat çekiciydi. Mütareke ahkâmının uygulanmasında bir beis görmeyen hükümetler, ülkede görevli sivil-asker bütün bürokratlara ve kamuoyuna bu durumun geçici olduğunu, asıl barış görüşmelerinden en az zayiatla çıkılacağı hususunda bir takım telkinlerde bulunarak durumu tevil etmeye çalıştı.

Mütareke ahkâmına itiraz edenler ise görevlerinden azledilerek İstanbul'a çağrıldı. Bu aşamada var olan duruma muhalif olanlar ya hapse ya sürgüne ya da pasif görevlere çekildi. Bu kaderi paylaşanlar arasında birçok vatanperver bulunmaktaydı. Bunlardan birisi de Mustafa Kemal Paşa idi. Kendisi 13 Kasım 1918'de İstanbul'a avdet etti. Burada yaklaşık altı ay kaldı. Kendisiyle aynı kaderi paylaşan arkadaşlarıyla bir dizi faaliyetler yürüttü. Ancak başarılı olamadı ve Anadolu'ya giderek milletle beraber kurtuluş çareleri aramanın doğru olacağı kanaatine vasıl oldu. $\mathrm{Bu}$ aşamadan sonra da vazife başındaki vatanperver Osmanlı bürokratlarının da desteğiyle IX. Ordu Kıtaat-ı Müfettişliği ihdas edilerek Anadolu'ya fevkalade yetkilerle görevlendirildi. Mustafa Kemal Paşa ve karargâh1 19 Mayıs 1919'da Samsun'a çıktı. $\mathrm{Bu}$ andan itibaren kendisinin Anadolu'ya gönderilme gerekçelerini bir kenara koyarak Anadolu'nun yeniden bağımsız ve hür bir şekilde yaşaması için uğraş içinde oldu. Mustafa Kemal Paşa'nın bu çabalarına en büyük destek ise İstanbul'da görüştüğü arkadaşları oldu. Bunlar arasında Kazım Karabekir Paşa, Ali Fuat Paşa ve Rauf Bey gibi komutanlar vardı. Bu isimler de bir şekilde yolunu bularak daha önceden çeşitli görevlerle Anadolu'ya geçerek çalışmalarını sürdürmekteydiler.

\section{Erzurum'da Milli Teşkilatlanma Çabaları}

Erzurum'da ilk milli teşkilatlanma Mondros Mütarekesi'nden kısa bir süre sonra halkı bir arada tutmak maksadıyla başlatıldı. Ülkenin değişik mahallerine paralel olarak, İstihlâs-1 Vatan Cemiyeti adıyla kurulan teşkilat bir taraftan Erzurum'da teşkilatlanırken diğer taraftan da Elviyei Selase de başlatılan kongre tipi devletleşme çabalarına el altından destek vererek, işbirliğini sürdürdü (Selvi, 2000, s. 38).

$\mathrm{Bu}$ esnada mütareke uygulamaya konulunca özellikle de doğu vilayetlerinde bir Ermeni Devleti'nin kurulacağını dair söylentiler karşısında Meclis-i Mebusan'da doğulu mebuslar harekete geçerek, önce Meclis'te Vilayat-1 Şarkiyye grubunu kurmuşlard1. Bu gibi konularda hassasiyeti olan bölge mebusları ve ileri gelenleri bir araya gelerek "2 Aralık 1918'de Vilayat-1 Şarkiyye Müdafaa-i Hukuk Cemiyeti'nin kurmuşlardır.” (Selvi, 2000, s.51). Akabinde de bölgede teşkilatlanmak için çaba içinde olunmuştu. Erzurum'da İstihlas-1 Vatan Cemiyetiyle başlayan sağlam duruş şehirde kendini gösteren İttihatçılık tartışmalarının gölgesinde kalmış ve bir anlamda itibar kaybetmişti. Bu ortamda milli teşkilatlanma süreci Dursunbeyzâde Cevat Bey'in İstanbul'dan cemiyet adına Erzurum'a gelmesiyle yeni bir ivme kazanmış ve Vilayat-1 Şarkiyye Müdafaa-i Hukuk Cemiyeti'nin bir şubesinin Erzurum'da açılması için çalışmalar başlatılmıştır. Bu çabaların neticesinde de 11 Mart 1919'da Cemiyetin, Erzurum şubesi fiilen kurulmuştu. 
Tayyip Gökbilgin'e göre “Erzurum Müdafaa-i Hukuk Teşkilatına asıl kuvvet veren şey, bu memleketlerin heyecanlı evlatlarının durmadan, bütün güçlüklere rağmen yeis getirmeden yaptıkları teşebbüs ve çalışmalardı. Bilhassa Süleyman Necati’nin çıkardığı Albayrak gazetesi bütün milli iradeye tercüman oluyordu." Ancak Erzurumluların bütün gayretine rağmen hedefe ulaşmak için askeri güce de ihtiyaç vardı. O esnada Yakup Şevki Paşa'nın bölgede görev yapması çalışmaları teşvik edici olmuşsa da rahatsızlığı nedeniyle aktif faaliyetler içinde olamamıştı. Kendisinin İstanbul'a gitmek zorunda kalması üzerine yerine Kazım Karabekir tayin olmuştu. Böylece Cemiyet, aradığı desteği ve hamiyi bulmuş ve çalışmalarını bu heyecanla yürütme imkânına kavuşmuştu (Gökbilgin, 1959, s.73-74).

Bu esnada; 12 Şubat 1919'da kurulan Trabzon Muhafaza-1 Hukuk-1 Milliye Cemiyeti ilki 13 Şubat 1919'da ikincisi de 28 Mayıs 1919'da kongreler tertip ederek bölgenin geleceği ile ilgili çok önemli kararlar almıştı. Trabzon merkezli yapılan bu çalışmalar devam ederken Erzurum'da Vilayat-1 Şarkiyye Müdafaa-i Hukuk-1 Milliye Cemiyeti, altı doğu vilayeti ile yazışmaları yaparak büyük bir kongrenin toplanacağı hususunda alınan kararları bildirmişti. Her iki cemiyetin ortak tavrı ortaya çıkınca Erzurum'da bir kongrenin yapılması süreci de hızlanmış oldu. Ülkenin geleceğini belirleyecek büyük kongreden evvel Erzurum Vilayat-1 Şarkiye Müdafaa-1 Hukuk-1 Milliye Cemiyeti bir vilayet kongresi toplamak gereğini duydu. 17- 21 Haziran 1919'da tarihleri arasında gerçekleştirilen bu kongreye bütün kazalardan seçilmiş temsilciler katılmıştır. Bu kongrede alınan kararları Cevat Dursunoğlu şöyle izah etmektedir:

1- Dilekte olduğu gibi işte de birliği sağlamak,

2- Osmanlı camiasından ayrılmamak için her türlü ihtimali göz önüne alarak bu yolda hiçbir fedakarlıktan çekinmemeyi umde olarak kabul etmek,

3- Her ne suretle olursa olsun memleket bir Ermeni saldırısına uğrarsa bunu şiddetle karşılamak ve milli varlığımızı son ferdin ölümüne kadar savunmak,

4- Bunun için herhangi bir toprak üstünden milli varlığı silen hicret fikrini kesin olarak zihinlerden çıkarmak,

5- $\mathrm{Bu}$ işleri başarabilmek için her şeyden ziyade orduya güvenmekle beraber "bekçi teşkilatı" adı altında halkı hususiyle köylüyü silahlandırmak (Dursunoğlu, 1946, s.67).

Vilayet kongresinin aldığı bu kararlarının bir an evvel hayata geçirilmesi gerekiyordu. $\mathrm{Bu}$ bağlamda yapılan ilk iş, alınan kararlar doğrultusunda bölge insanını silahlandırmak oldu. Hazırlanan talimatlar doğrultusunda bu çalışmalar sürdürülürken cemiyetin ilçe ve köylere kadar idare heyetleri oluşturarak teşkilatlanmasını tamamlamaya çalıştıkları anlaşılmaktadır. İşte bu gibi çalışmalarla 10 Temmuz'da toplanacak Erzurum Kongresi'nin altyapısı hazırlanmış oldu.

\section{Mustafa Kemal Paşa'nın Erzurum'a Gelişi ve Kongre Hazırlıklarına Katılması}

Erzurum'da yukarıda ifade edilen çalışmalar yapılırken resmi görevle Anadolu'ya gönderilen Mustafa Kemal Paşa'nın Samsun'dan Erzurum'a doğru yolculuğu 45 gün sürdü. Bu yolculuk Mustafa Kemal Paşa ve karargahı için çok anlamlıydı. Bir taraftan resmi görevli olarak kendisinden beklenilen vazifeler bir taraftan da ülkenin içinde bulunduğu nazik şartlar karşısında bir vatanperver olarak resmiyet dışı faaliyetleri yürütmesi, İstanbul ve işgal kuvvetlerinin tepkisi ile karşılanmış ve çok ciddi sıkıntılar yaşanmıştır. Ancak gelinen aşamada İstanbul'a geri dönmek gündem dışına çıkarılmıştı. $\mathrm{O}$ artık halkın arasına girmiş resmi kıyafetli de olsa bir lider 
rolünü yakalamıştı. Yolculuk esnasında en çok güvendiği isimlerden birisi de Erzurum'da bulunan XV. Kolordu Komutanı Kazım Karabekir idi. Onun varlığı ve açık desteğinin net olması Mustafa Kemal Paşa açısından iyi bir dayanaktı. Kaybedilecek zaman kalmamıştı. Bir an evvel Erzurum'a gitmeliydi. Nihayetinde 45 günlük zorlu yolculuk 3 Temmuz 1919'da son buldu. Heyeti Kazım Karabekir Paşa ve Erzurumlular büyük bir coşkuyla karşıladı.

Mustafa Kemal Paşa, Erzurum'a geldiği günü dinlenerek geçirdi. Ertesi günü de ilk iş olarak Yaveri Cevat Abbas Bey'i, Müdafaa-i Hukuk-1 Milliye Cemiyeti'ne göndererek ziyarette bulunacağını bildirdi. Mustafa Kemal Paşa, üniformalı ve yaver kordonları ve bütün nişan madalyaları takılı bir halde, yanında Rauf Bey ve İbrahim Süreyya Bey olduğu halde ziyarete gitti (Dursunoğlu, 1946, s.90-91). Bu ziyarette yaşanan gelişmeler ve yakında yapılacak kongre hazırlıkları konuşuldu (Dursunoğlu, 1946, s. 90). Nutuk'ta da bu konuda “Erzurum'a muvasalatımın ilk günlerinde Erzurum Kongresi'nin in'ikatını temin için ittihaz-1 tedabir ile iştigale ehemmiyet verildi” denilmektedir (Atatürk, 1989, s. 31).

İstanbul ile ilişkiler iyice gerilmiş ve kopma noktasına gelmişti. Harbiye Nazırı Ferid Paşa, 5 Temmuz'da Mustafa Kemal Paşa'ya çektiği telgrafta, İstanbul'a geri dönmesi çağrısını yeniden yapmış ve telgraf başında görüşmek istediğini iletmişti. Bunun üzerine Mustafa Kemal Paşa da gerekli tedbirleri alarak postaneye gitmişti (Oranlı, 1967, s. 20-21). Telgraf başında yapılan görüşmelerde Nazır Ferid Paşa, son derece dikkat çekici şu telgrafı çekmişti: "Paşam! İtilaf mümessillerinin pek kati müracaatları bugünkü telgrafnâmemi yazmaya mecbur etti. Zât-1 âlilerini benim kadar kimse bilmez. Hamiyet-i vataniyelerinin ulvi gayelerine vakıfım.

Bendeniz İstanbul'a teşrif buyuracağını gerek Şevketmeâb Efendimize ve gerek mümessillere karşı taahhüd eyledim. Mahcup olmayacağıma eminim.” (TBMM-ZC, I/1, 1981, s.13).

Telgraf başında devam eden uzun yazışmalardan bir sonuç alınamadığı için görüşmelere son verilmişti. Bu görüşmelerden Mustafa Kemal Paşa'nın İstanbul'a dönmeyeceği anlaşılıyordu (Tansel, 1991, s.34). Zaten İstanbul'a çektiği son telgrafinda da Doğu Anadolu'yu Ermenilere bırakma sözü verenlerin isteğine göre geri dönmeyi züll kabul ettiğini ve bu durum karşısında kendisini "maddi ve manevi olarak yasaklanmış" (Onar, 1995, s. 100; Tansel, 1991, s. 34) bulduğunu cesaretle dile getirmişti.

İstanbul ile yaşanan sinir harbi devam ederken 5 Temmuz'da da Mustafa Kemal Paşa'nın reisliği altında Erzurum Kale Muhafizlı̆̆ı'na ait bir binada gizli toplantı yapıldı (Kansu, 1988, s. 30). Celal Bayar'ın “Amasya Mülakatı'nın ikincisi” dediği (Bayar, 1972, s. 2623). Erzurum'da yapılan bu iki toplantıda Mustafa Kemal Paşa, ülkenin içinde bulunduğu durumu iştirakçilere ${ }^{2}$ izah ederek bu hal karşısında yapılması gerekli hareket tarzını anlattı. Milli gaye için ortaya atılacakların şartlar ne olursa olsun gayeden dönmemesini, hedefe varıncaya kadar, son nefeslerini verinceye dek gaye uğrunda her türlü fedakârlıktan kaçınmamaları gerektiğini bütün açıklığıyla izah etmişti (Omurtak, 1970, s. 67). Mazhar Müfit Beyin anlattıklarına göre; Mustafa Kemal Paşa o gece nihaî hedefi şöyle belirtmişti: "Hakimiyet-i Milliye'ye müstenid bilakayd-ü şart müstakil bir Türk Devleti teşkil etmek ve bu hedefe behemahal vasıl olmaktır." (Kansu, 1988, s. 32; İstiklal Savaşı Gazetesi, 5 Temmuz 1919).

\footnotetext{
${ }^{2}$ Toplantıya katılan zevat: Mustafa Kemal Paşa, XV. Kolordu Kumandanı Kâzım Karabekir, Hüseyin Rauf Bey, Erzurum Valisi Münir Bey, İzmit Mutasarrıfi İ. Süreyya Bey, Ordu Müfettişi Erkan-1 Harp Reisi Kâzım Bey, Erkân-1 Harp Binbaşı Hüsrev Bey, Dr. Binbaşı Refik Bey ve Mazhar Müfit Bey. (Kansu, 1988, s.30)
} 
Mustafa Kemal Paşa, Erzurum'a geldiği günden beri faaliyetlerini aleni yapıyor ve yaptıklarının İstanbul'daki tepkisini de açıkça önemsemiyordu. Milli Mücadele karşıtı İstanbul basınının, Mustafa Kemal Paşa ve Milli Mücadeleye karşı başlatmış olduğu propagandalar kısa sürede yankı bulmuş olmalı ki, bir müddet ara verdikleri karşılıklı yazışmalar 8/9 Temmuz gecesi yeniden başlatılmıştı.

$\mathrm{Bu}$ sefer Mustafa Kemal Paşa'yı makine başına çağıran bizzât Padişah'tı. Yapılan uzun görüşmeler neticesinde Padişah, Mustafa Kemal Paşa'nın İstanbul'a geri dönmesi halinde her türlü fedakârlığa hazır olduğunu bildirdi. Mustafa Kemal Paşa ise ne pahasına olursa olsun İstanbul'a dönmeyeceği fikrinde 1srarc1 olunca, Saray "O halde resmi vazifeniz sona ermiştir" (Tansel, 1991, s. 38) diyerek tavrını ortaya koymuştu.

Bunun üzerine de Meclis-i Vükelâ, Şeyhülislam ve Sadrazam Vekili Mustafa Sabri'nin reisliğinde toplanarak Mustafa Kemal Paşa'nın vazifelerine son vermişti (Atatürk ile İlgili Arşiv Belgeleri, 1982, s. 48-49; Bayar, 1972, s. 2637). İngilizlerin baskıları sonucu alındığı aşikar olan bu kararı Padişah Vahdettin de onaylayarak iradesini eklemişti (Belgelerle Türk Tarihi Dergisi, 14/Kasim-1968, s. 12).

Bunun üzerine Mustafa Kemal Paşa (TİTE, K. 16, G. 62, B. 62) başta olmak üzere Rauf Bey (HTVD, I/2 -Aralık 1952, Vesika No: 37; Kırzıoğlu, 1993, s. 140), Kâzım Karabekir Paşa (TİTE, K. 19, G. 44, B. 44), Ali Fuat Paşa (Cebesoy, 1993, s. 99; İstiklal Savaşı Gazetesi, 11 Temmuz 1919), Selahattin Bey (Tansel, 1991, s. 40-41) vs. bu komutanların hepsi de yayınladıkları beyannâmelerle Amasya kararlarına sonuna kadar uyacaklarını Mustafa Kemal Paşa istifa etse de kolordularıyla beraber kendisinin yanında olduklarını, bu kararlarını bütün Redd-i İlhak ve Müdafaa-i Hukuk Cemiyetleri’ne bildirmişlerdi.

Anadolu'da bu karşı hareket netleşirken, bir taraftan Harbiye Nezareti, kolordulara telgraf çekerek Mustafa Kemal'in azledildiği ve bundan sonra da her türlü haberleşmenin doğrudan Harbiye Nezareti'yle yapılmasını istemişti. (HTVD, I/2-Aralık 1952, Vesika No: 30) Diğer taraftan da Dahiliye Nezareti, vilayetlere Mustafa Kemal ile her türlü ilişkinin yasaklandığını ve kendisinin artık tanınmamasını bildirmişti (B.O.A, DH-ŞFR, 101-19/35; B.O.A, DH-ŞFR, 10119/36;B.O.A, DH-ŞFR, 101-19/100).

İstanbul ile ipleri tamamen koparan Mustafa Kemal Paşa için, istifa sonrası Erzurumluların tepkisi çok önemliydi. Bunu merak eden Paşa, istifa sonrası Albayrak gazetesi sahibi Süleyman Necati Bey'i çağırarak onun vasıtasıyla Müdafaa-i Hukuk-1 Milliye Cemiyeti'nin bu konudaki görüşlerini öğrenmek istemişti. Süleyman Necati Bey’e istifa yazısı gösterildiğinde; "Millet de layık olduğunuz mevkiye iş'ad etmekde gecikmeyecektir” (Güneri, 1999, s. 63; Selvi, 2000, s. 98) cevabını vermiş ve son durum hakkında Müdafaa-i Hukuk Cemiyeti'ne bilgi vermek üzere oradan ayrılmıştı.

Ertesi gün Mustafa Kemal Paşa, Erzurum vilayetine gönderdiği yazıyla da istifa ettiğini açıkça belirtmiş (Unat, 1962, s. 2), Süleyman Necati Bey ise; Albayrak gazetesinde; “Anafartalar'da ulusun onurunu, tarihin bugünkü kuşaklarından beklediği görevi gür sesiyle yükselten bu sayın komutanı, bugün de Milli Mücadele'nin başında görmek mutlu bir temaşadır." (Arıburnu, 1997, s. 38) ifadeleriyle bir anlamda Mustafa Kemal Paşa'ya Erzurumluların sahip çıktığını duyuruyordu. 
$\mathrm{Bu}$ sırada Mustafa Kemal Paşa'nın istifası Müdafaa-i Hukuk-1 Milliye Cemiyeti'nde görüşülmüş, yapılan değişikliklerle de Mustafa Kemal Paşa ve Rauf Bey, Heyet-i Faale'ye seçilmişlerdi. Cemiyet bunları onure etmek için de Mustafa Kemal Paşa'yı Heyetin Reisliği'ne, Rauf Bey de ikinci Reisliğe kabul etmişti (Dursunoğlu, 1946, s. 92; Güneri, 1999, s. 64; Selvi, 2000, s.104-105) Mustafa Kemal Paşa ve Rauf Bey, bu teklifi memnuniyetle kabul etmişler (Arıburnu, 1997, s. 39) ve Heyet-i Faale'yi zaman kaybetmeden toplantıya çağırmışlardı. ${ }^{3} 10$ Temmuz 1919 günü öğleden sonra yapılan toplantıya heyet tam katılmış ve ülkenin içinde bulunduğu genel durumu izah ile asıl gündem maddesi olan kongrenin açılması görüşülmüştü. Ancak kongre hazırlıkları tam olarak yapılamadığı ve delegelerin gelmesi beklendiği için daha önce belirlenen tarih değiştirilmiş, 23 Temmuz'da kesin olarak yapılması kararlaştırılmıştı (Selvi, 2000, s. 103). Kongre tarihinin 23 Temmuz olarak belirlenmesi ise son derece anlamlıydı. Çünkü 23 Temmuz Osmanlı Devleti'nde II. Meşrutiyet'in ilân günü idi (İstiklal Savaşı Gazetesi, 14 Temmuz 1919).

Netice itibariyle Mustafa Kemal Paşa, sivil olarak Erzurum'da kaldığı süre boyunca dışardan gelen temsilcilerle bol bol görüşme imkanı bulmuş ve kongre hazırlıklarının eksiksiz yapılması için yoğun çabalar içine girmişti.

\section{Kongre Sürecinde Dikkat Çeken Tartışmalar}

Vilayat-1 Şarkiyye delegelerinin katılımıyla Erzurum'da 10 Temmuz'da bir kongrenin toplanması kararının ardından başlanılan kongre hazırlıkları hem Cemiyet üyeleri hem de Erzurum halkının desteği ile aşağı yukarı tamamlanmıştı. Kongrenin toplanma amacı ve hedefleri dikkate alınarak hazırlıkların yapılma aşamaları Erzurum Vilayat-1 Şarkiye Müdafaa-ı Hukuk-1 Milliye Cemiyeti'nin bu kongredeki diğer partneri Trabzon Muhafaza-1 Hukuk-1 Milliye Cemiyetince de dikkatle takip edilmişti.

Bu bağlamda Gümüşhane Muhafaza-i Hukuk-1 Milliye Reisi ve Murahhası Kadirbeyzade Ahmet Bey tarafindan Erzurum'da Hoca Raif Efendi ve Kazım (Yurdalan) Bey'e yazılan 25 Haziran 1919 tarihli bir mektup son derece dikkat çekici ve uyarıcı mesajlar vermekteydi. "Bu dakikada her tarafindan gelen murahhaslar vazifesi neden ibaret olduğunu bilerekten geliyor, fikrindeyim. Ümidim, kongrede müdafaa hususundaki teşkilattan başka bir şey işitilmemektir." ifadeleriyle kongrenin toplanma amacının tertip heyetine iyi anlatıldığına inanmak istediğini, başka düşüncelerin kongreye hakim olmamasının altını çiziyordu. Ayrıca, "Bugün Erzurum Kongresi her kuvvetin fevkinde ve anında teşkil edeceği heyet-i merkeziye hiç bir taraftan emir almayacak kadar büyük olmalıdır... Yalnız bir emr-i vaki karşısında bulunmaktan korkuyorum." (Akbulut, 1989, s. 13-14) sözleriyle Mustafa Kemal Paşa ve Kazım Karabekir'in yönlendirmelerine dönük üstü kapalı uyarıların yapılmış olması kongre sürecinin tartışmalı geçeceğine dair işaretler vermekteydi. Yine kongre sürecinin sağlıklı bir ortamda yapılması için kongre salonunun tespitinden, murahhasların ağırlanmasından, kalacak yerlerinin ayarlanmasına her türlü tefrişin yapılmasının gerekliliği hususunda çalışmaların yapılmasının kongrenin prestijini artıracağının vurgulanması dikkat çekici olmuştur (Akbulut, 1989, s. 14).

\footnotetext{
3 "Leffen takdim kılınan talimat da muharrer olduğu vechile vezaifi muhtelif-i vataniyye ile mükellef bulunan Heyet-i Faalemiz Riyaseti'nin Zâtı-Sâmîleri; ve Riyaseti- Sâniyesi'nin, Muhterem (Hüseyin) Rauf Beyefendi Hazretleri tarafindan kabul buyurulmasını; ve Heyeti marûzaya Heyetimizden de bâlâ da esamîleri muharrer zâtların tayin ve tefrik edildiğinin arziyle, temennîi muvaffakiyât ve kesbi şeref eyleriz." (Kırzıoğlu, 1991, s.11) 10 Temmuz 1919'da ve Vilayat-1 Şarkiyye Müdafaa-i Hukuk Cemiyeti şube reisi Raif Bey imzalı tezkereyle davet edilmeleriyle kongre süreci pro-aktif olarak yürütülmeye çalışıldığı görülmektedir.
} 
30 Mayıs 1919'da Erzurum ve Trabzon Müdafaa-i Hukuk Cemiyetlerinin işbirliği ve yedi vilayetin katılımıyla yapılacak olan kongreye iştirak edecek olan vilayetlere tebliği ve buradan seçilecek olan delegelerin zamanında ve gerekli tedbirler alınarak kongreye katılımlarının sağlanması istenmişti (Baykal, 1969, s. 6-vd.). Ancak bu yeni gelişmeyi anlayamayan İstanbul taraftarı kimi yöneticiler delege seçimleri veya seçilen delegelerin Erzurum'a gitmelerine engel olmak istemiştir. Bununla da kongre çalışmasının meşruiyetini tartışmaya açmak yolunu tercih etmişlerdi. İşte 10 Temmuz'da yapılması düşünülen kongrenin 23 Temmuz'a ertelenme gerekçesi böylece ortaya çıkmıştı.

$\mathrm{Bu}$ gelişmelerin olduğu günlerde en çok tartışılan konulardan biri de Mustafa Kemal Paşa ve Rauf Bey'in kongreye katılıp katılmamaları ve kongre reisliğine seçilip seçilmemeleri idi (Selvi, 2000, s. 104). Kongre çalışmalarına aktif bir şekilde katılabilmeleri için Mustafa Kemal Paşa ve Rauf Bey'in herhangi bir yerden delege seçilmeleri gerekiyordu. Her ikisi de kongreye Erzurum delegesi olarak katılmayı arzulamaktaydı. Bu maksatla Mustafa Kemal Paşa ile Erzurum'a gelen İbrahim Süreyya, Mazhar Müfit gibi isimler cemiyet ile temaslarını artırarak kongreye delege olarak katılmaları için çalışmalar yapıyorlardı. Bu duruma bir mana veremediğini ifade eden Cevat Bey, "Paşa'yı Heyet-i Faale reisliğine seçmiş olduğumuzdan kongreye girmesini tabii buluyorduk. Kongre reisliğine seçileceğinde de şüphemiz yoktu." demekteydi (Dursunoğlu, 1946, s. 97-98).

Meselenin bu raddeye gelmesinde Mustafa Kemal Paşa ve heyeti aleyhinde bazı çevrelerce yapılan kara propagandanın da etkisi vardı. Karabekir'e göre bu hassas dönemlerde "Mustafa Kemal Paşa azlolunmasına ve kendisinin de askerlikten istifasına rağmen ne üniformasını ne de padişah kordonunu çıkarıp atmamasının da tesiri vardı.” (Karabekir, 1990, s. 70).

Kongrenin toplanacağı gün yaklaştıkça seçilmiş delegeler de Erzurum'a gelmeye başlamıştı. Özellikle Trabzon delegelerinin gelmesinden sonra bu tartışma daha da ciddi boyutlara taşınmıştı. Cemiyetin tavrı ortada idi. Dışarıdan gelenlerin tavrı ise bilinmiyordu.

Cemiyet reisi Hoca Raif Efendi, Trabzon delegelerinin tavrını öğrenmek için onlarla yaptığı bir toplantıda ilginç diyaloglar ve tartışmalar yaşandı. Maçka delegesi İzzet Bey, bir an önce Cemiyetin kongre delegelerini seçmesi gerektiğini Hoca Raif Efendi'ye ifade edince Raif Efendi bu ifadelerin Cemiyetin içişlerine müdahale olduğunu söyleyerek tepki gösterdi (Eyyüpoğlu, 2009, s. 237). Bunun üzerine Gümüşhane delegesi Kadirbeyoğlu Zeki Bey ise "Ne gibi müdahale? Henüz murahhaslarımızın kimler olduğunu bile bilmiyoruz. Evvela seçmek istediklerinizi bir öğrenelim, dedim. Raif Efendi: Mesela sabık Bahriye Nazırı Rauf Bey ile Ordu müfettişliğinden istifa eden Mustafa Kemal Paşa'yı seçmek istiyoruz. Bunların her ikisine de Trabzon murahhasları itiraz ediyorlarmış, dedi. Ben: Size bu fikri kim verdi, Erzurum'da kongreye iştirak edecek kimse yok mudur, yoksa murahhaslarınızın muhakkak reis olmasını ve onun riyasetini temin için de bir paşa olmasını mı istiyorsunuz? Sizlere çok rica ederim bu işe askeri kuvveti karıştırmayınız. Yoksa ara yerde şahsi bir mesele yoktur, dedim. 
Ertesi sabah salonda toplanıp arkadaşlara durumu anlattık. Giresun murahhası Doktor Naci ve Sürmene murahhası Ömer Fevzi Beyler hiçbir vakit bir kumandanın idaresinde kongrede bulunamayacaklarını söyleyerek aleyhte bulundular. Meseleyi uzatmayı muvafik bulmadığımızdan mübahaseye nihayet verdik.

Öğleden sonra Hoca Raif Efendi ile görüşmek istedik ve onu medresede bulduk. Yanında Hoca Necati Efendi vardı. İkisi birlikte Erzurum murahhaslarını tayin ediyorlard1. Servet Bey: Kongre bu işi halledecektir, dedi. Raif Efendi: Ne demek istiyorsunuz? Kongre neyi halledecektir? diye sordu. Servet Bey: Mazbataların tetkiki ile kabul ve ademi kabulünü. Biz 37 murahhas olarak geldik. Herbiri bir memleket ahalisindendir. Bunları oradaki Müdafaa-i Hukuk Cemiyetleri ile belediyeler müşterek olarak seçtiler ve ellerine birer mazbata verdiler. Bununla beraber herhangi birimiz hakkında vuku bulacak ihbar üzerine tahkikat ve tetkikat yapmak kongreden seçilecek bir heyet ile bakmak mecburiyeti vardır, diye anlattı. İzzet Bey: Bu ciheti Zeki Bey bilmese hakkı vardır, çünkü mebusluk yapmamıştır. Biz her üçümüz de bildiğimiz şey üzerinde beyhude vakit geçiriyoruz, müsaadenizle gidelim, dedi. Misafir hanemize geldik.

Gece arkadaşlarla otururken hizmetimize bakan Mehmet Ağa bana bir işaret verdi. Yanına yaklaştığı vakit de Kazım Karabekir Paşa'nın bizim odada beklediğini söyledi. Ben de gizlice İzzet ve Servet beylere haber vererek aşağı indim. Onlar da geldiler. Karabekir Paşa, Hoca Raif Efendi'nin kendisini ziyaretle Mustafa Kemal Paşa'nın Erzurum murahhaslığına itiraz ettiğimizi söylediğini bildirdi. İzahatının sonunda da "ricamı şu suretle de teyit etmek isterim ki Trabzon grubundan herhangi bir arkadaş bu hususta hiçbir itirazda bulunmamasının teminini her üçünüzden ayrıca istirham edeceğim. Hususi ziyaretin bu maksada matuf idi” dedi bunu kabul etmekte muztar kalarak ilk evvel Servet Bey "Paşam mademki böyle arzu ediyorsunuz, her birimiz ötekimiz adına söz verebiliriz, ben İzzet ve Zeki beyler adına söz veriyorum, buna bütün mevcudiyetimizle çalışacağız" dedi. Paşa teşekkür ederek gitti." (Goloğlu, 1968, s.178-179).

Trabzon heyeti Mustafa Kemal Paşa ve Rauf Bey'in delege olup olmamasında ya da kongreye aktif katılıp katılmama meselesindeki çekincelerinin sebebini Karabekir Paşa ile yaptıkları bir başka görüşmede de dile getirmişlerdir. Bu mevzuda Kadirbeyoğlu Zeki Bey'in hatıralarında şu bilgiler dikkat çekicidir: "Evet, biz de bu hakikati muterif bulunuyoruz ki Erzurum vilayetinin intihab edeceği herhangi bir murahhasa diğer bir vilayetin müdahale etmesine ne hakkı vardır.

Bunda Erzurumluların yerden göğe kadar hakları vardır. Hatta bir kaza merkezinin de intihab edip gönderdiği murahhası başımızla kabule hazırız. Yalnız bizim bir düşüncemiz vardır.

$\mathrm{Bu}$ düşünceyi halletmek icab eder. O da bu milli hareketi gayr-i askeri bir kuvvetle idare ederek başa çıkarmaktır. Tarih önümüzde çok canlı bir misaldir. Askerin yapacağı herhangi bir inkılab, ihtilal neticesi tasallut ve diktatörlükle hitam bulur. Kazanıldığı takdirde diktatör ilk evvel kendisine yardım edip zahir olarak kendisini içeri alan arkadaşlarını tepelemek, asmak, kesmek ondan sonra da yeni türedi müptezel mütebasbıs birçok bendegân içerisinde darat ve azamet sürmek değil midir? Böyle okuduk ve bunlara görmüş gibi iman ettik. Gördük yok, şayet ihtilal ve inkılab muvaffak olmazsa hepimizin vücudu başlarına seyrangaha çoktan bırakmış olacaktır. Paşa, iki defa Havza'dan telgrafla Trabzon'a bize müracaat etmişti. Verdiğimiz cevabda dahi bu ciheti işrap değil de açık bildirmiştik. Bunun için milli kuvvetin ayaklanması milli halk idaresinin halka tattırılması için bu inkılaba şüpheli eşhasın girmemesini rica ederiz." (Kadirbeyoğlu Zeki, 2007, s. 41-42). 
Mustafa Kemal Paşa ve Rauf Bey'e karşı tavır içinde bulunan bazı Trabzon delegeleri de bunları İttihatçı olarak gördüklerinden olsa gerek ülkeyi felakete sürükleyen İttihatçılar endişeleri sebebiyle mesafeli ve ihtiyatlı bir duruş sergiliyorlard1. Bundan dolayı da kongrenin hükmü şahsiyetine, tarafsızlığına gölge düşüreceği endişesi içinde oldukları görülmekteydi (Eyyüpoğlu, 2009, s. 238). Yukarıda ifade edilen görüşmelerde de görüleceği üzere milli irade, seçim, demokrasi ekseninde kongrenin toplanması Trabzonlu delegelerin temel istekleri olarak öne çıkıyordu.

Görüleceği üzere tartışmalar ve anlaşmazlıklar can sıkıcı boyutlara gelmişti. Bundan dolayı bu meselenin bir an evvel halledilmesi gerekmekteydi. Mustafa Kemal Paşa ve Rauf Bey'in hazır bulunduğu cemiyet toplantısında bir karar verilecekti. Ancak Erzurum'da delege seçimleri tamamlanmış olduğundan nereden seçilecekleri hususu netlik kazanmamıştı. Burada yapılan görüşmeler neticesinde kongre Erzurum heyet-i merkeziye namına daha evvel seçilmiş olan Kazım (Yurdalan) ve Cevat Beyler kendi iradeleri ile istifa etmeleri ve yerlerini Mustafa Kemal Paşa ve Rauf Bey'in seçilmeleri iradesi tezahür etmiş ve mesele uhuletle bir çözüme kavuşturulmuş oldu. Akabinde de henüz kongreye kimlerin katılacağı bildirilmeyen Tortum'dan Kazım Bey'in, Hasankale'den de Cevat Bey'in namzet gösterilerek kongre delegesi olmalarıyla mesele bu boyutuyla da halledilmiş oldu (Dursunoğlu, 1946, s. 98-99; Eyyüpoğlu, s. 241-242).

Erzurum Kongresi'nin toplanacağı gün yaklaştıkça yeni tartışmalar da ortaya çıkmaya başlamıştı. Tam da delege meselesi halledilmişken yeni tartışma; kongre reisliğine kimin getirileceği ve kongrenin hangi cemiyet adına düzenleneceği belirsizliği gündeme getirilmişti. $\mathrm{Bu}$ yeni durumla ortam iyice gerilmişti. Henüz kongre toplanmamışken vuku bulan bu tartışmalar gerekli miydi? "Delegelerin bir kısmına göre kongreye askerler girmemelidir. Hatta etraftan veya yakından kongre ile temas halinde dahi bulunmamalıdırlar. Çünkü kongrenin tamamıyla milli irade mahsulü olduğuna değil, askerlerin tertip ve baskısı altında düzenlenmiş olduğu izlenimini vereceğini düşünmektedirler.” (Eyyüpoğlu, s. 245). Özellikle Trabzon delegeleri, reisliğe namzed gösterilen Mustafa Kemal Paşa'nın eski bir İttihatçı olması, Padişahın Fahri Yaveri kıyafetleriyle dolaşması milli bir davranış sayılamayacağı görüşündeydiler (Akandere, 2015, s. 33).

Kongre günü yaklaşıp hazırlıklar tamamlanmaya çalışılırken 20 Temmuz'daki toplantıda usul ve hukuk anlayışına itirazlar gelmişti. Başta Trabzonlu delegeler olmak üzere başka vilayet delegeleri de bu tartışmaya dahil olmuşlardı. Mesele şuydu: Erzurumlular ve Cemiyet, merkezi İstanbul'da bulunan Vilayat-1 Şarkiye Müdafaa-1 Hukuk-1 Milliye Cemiyeti adına kongrenin toplanacağını, kararlar alacağını, dolayısıyla da genel merkezi temsil eden birinin kongre reisi namzedi olacağı, bu ismin de Mustafa Kemal Paşa olması hususunda yönlendirici olmak istediklerinde Trabzon delegelerinin bu isteklere ve dikte edilmesine tepkileri sert oldu. Onlara göre kendileri Trabzon Muhafaza-1 Hukuk-1 Milliye Cemiyeti adına buralarda olduklarını, eğer kongre Vilayat-1 Şarkiye Müdafaa-1 Hukuk-1 Milliye Cemiyeti adına yapılacaksa kongreye sadece Erzurum delegelerinin katılmasının doğru olacağını, dolayısıyla kendilerinin katılmama kararı alacaklarını ifade etmişlerdi. Bu vakte kadar verilen Milli Mücadelenin İstanbul'dan bağımsız olarak devam etmesinin doğru olacağında 1srar etmişlerdi. Cemiyet şube reisi Hoca Raif Efendi ise kongrenin İstanbul'daki cemiyet adını açılmasında ısrar etmişti. Sonunda taraflar durumun İstanbul'da Cemiyet genel merkezi ile paylaşılmasını, genel merkez adına Mustafa Kemal Paşa'ya söz, oy hakkı ve yetkisi verilmesinin uygun olup olmayacağı hususunda bir 
uzlaşı sağladı (Goloğlu, 1968, s. 70-71; Dursunoğlu, 1946, s. 103). Böylece kongre süreci dağılma tehlikesini atlatmış oldu. Bunun üzerine 21 Temmuz 1919'da Vilayat-1 Şarkiye Müdafaa-1 Hukuk-1 Milliye Cemiyeti Erzurum şubesi reisi imzalı bir telgraf İstanbul'da Cemiyetin genel merkezine gönderildi. Bu telgrafta kongre ve Mustafa Kemal Paşa hakkında özel bilgiler paylaşıldıktan sonra şunlar istenmiştir:

"Millet ve vatan uğrunda bu suretle ibrazı fedakâri eden bu Zatı Aliye karşı, yine kendisinini bir hıdmeti mübeccele-i vataniyeye davet suretiyle haklarında, Heyet-i Aliyyeleri tarafindan ibrazı asari takdir ve tebcilde bulunmuş olmak üzere, Merkezi Umumi Heyet-i Aliyyesi namına da beyanı rey ve mütalaa eylemek vazife ve selahiyetinin Paşay-1 Müşarünileyhe verildiğinin, telgrafla emir ve işar buyurulması, pek münasip olacağını arz ve istirham ederim. (Buna hiçbir cevap alınamamıştır.)" (Kırzıoğlu, 1991, s.15).

Diğer taraftan Trabzon delegelerinin kendi aralarında yaptıkları toplantıda da birtakım anlaşmazlıklar yaşanmıştı. Ömer Fevzi Efendi, daha önce konuşulan kongre reisliğine bir askerin getirilmek istenmesine itiraz etmesi ile görüş ayrılıkları yaşanmıştı. Bu durum karşısında Kazım Karabekir Paşa'nın inisiyatif alarak Trabzonlu delegelerle yaptığı görüşmeler neticesinde Mustafa Kemal Paşa'nın kongre reisliği meselesinde bir anlaşmaya varılmış oldu (Turan, 1991, s. 206-207).

Erzurum ve Trabzon delegelerinin bir şekilde uzlaşı sağlaması gerginliği azaltmıştı. Ancak bu sefer Sivas delegeleri ile başka bir tartışma vuku bulmuştu. Bu durumun sebebi ise 17 ve 19 Temmuz'da her iki cemiyet temsilcilerinin gizlice buluşup kongre programının taslağını hazırlamaları ve Mustafa Kemal Paşa'nın kongre reisliği meselesini görüşmeleriydi. Bu durumdan haberdar olan Sivaslı temsilciler Cemiyetin Erzurum şube reisliğine gönderdikleri yazı ile kendilerinden habersiz, gizlice yapılan bu toplantılarda alınan kararların objektif olmadığını alınan kararları tek taraflı olarak niteleyerek sert bir şekilde protesto etmişlerdi.

(Turan, 1991 s. 207; Selvi, 2000, s. 108). ${ }^{4}$

\section{Kongrenin Açılması ve Önemli Konularda Müzakereler}

Kongre öncesi yaşanan tartışmalar bundan sonra yaşanacakların da habercisiydi. Bu süreçte Karabekir Paşa'nın da ağırlığını koymasıyla kongrenin toplanmadan dağılması önlenmiş, taraflar bir şekilde uzlaştırılmıştı. Bunun ilk tezahürü de kongrenin açıldığı gün görülecekti.

Kongre, II Meşrutiyet'in ilanının yıldönümünde Rumi takvime göre 10 Temmuz, Miladi takvime göre 23 Temmuz 1919'da toplandı. Bu tarihler tesadüfi değil bilinçli tercihlerdi (Turan, 1991, s. 207). Çünkü bu tarihler ülkede "hürriyetin" ilanını ifade ediyordu. Kongre bir subliminal mesaj olsa gerek Ermeni Sanasaryan Mektebinde çalışmalarına başladı. Halkın kongreye ilgisi büyüktü. Katılımcılara büyük sevgi gösterileri sergilendi. Kongrenin toplanma saati geldiğinde asker şahıslar, daha önceki tepkiler dikkate alınmış olsa gerek kongrenin üzerinde herhangi bir vesayet izlenimi vermemek için salona girmeden ayrıldılar. Böylece çalışmalar başladı. Ayrıca önceden kongrenin basılacağına dair tehditlere karşı da birtakım güvenlik tedbirleri alındı.

\footnotetext{
4 "Erzurum Müdafaa-i Hukuk-1 Milliye Cemiyeti Riyaseti Canib-i Alisine,

Kongre'nin küşadından akdem, Heyet-i Umumiyye'ye aid bazı hususatın müzakeresi zımnında Trabzon Murahhas ları miyanında müntehab bir delegenin, sureti mahsusada davet ve müzakerata iştirak ettirildiğine 1ttıla hasıl edilmiştir. Mukadderatı milletle alakadar bulunan mesaile, Sivas mümessilleri iştirak ettirilmeyerek, tarafgirlik gibi bir hal ihsas ettirilmiş olmasından dolayı, vilayetimiz namına protestoya müsaraat eder; aynı maksat ve gayei vataniyye ile iktihami müşkilat ederek burada içtima eden Sivas mümessillerinin ihlas ve hissiyatı vatanperver anelerini rencide edecek, bu gibi ahvale, badema Meydan verilmemesini hasseten rica ile teyidi tanzimat eyleriz. Efendim.” (Kırzıŏlu, Belgelerle Türk Tarihi Dergisi (Dün-Bugün-Yarın), 35/Ağustos 1970, s.11-12.)
} 
Kongre, usul gereğince en yaşlı delege olan Trabzon delegesi İzzet Efendi tarafindan açıldı. İzzet Efendi, daha önce gerçekleşen uzlaşı gereği, nezaketen ev sahipliği de yapan, Vilayat-1 Şarkiyye Müdafaa-i Hukuk Cemiyeti Erzurum şube reisi Raif Efendi'ye reisliği bıraktı. Akabinde kürsüye çıkan Raif Efendi, ilk önce delege yoklaması yaptırdı. Birçok kaynakta farklı rakamlar telefuz edilse de Kırzıoğlu'nun beyannamelerde isimleri yazılı olanlardan hareketle tespit ettiği 63 kişinin kongreye gecikmeli de olsa katıldığı kabul edilebilir (Kırzıŏlu, 1993, s. 251-255; Çil, 2005, s. 70). Bu tespitten sonra Hoca Raif Efendi günün anlam ve önemine binaen konuşma yapmış ve "şu anda kongre küşade bulunduğunda devam ettiği müddetçe müzakerenizi idare ve vezaifi sairesini ifa etmek üzere bir reis intihabı buyurmanızı teklif ederim.” diyerek konuşmasını tamamlamıştı (Kırzıoğlu, 1993, s. 14).

Bu konuşmanın akabinde daha önceden ciddi tartışmalara sebebiyet vermiş olan kongre reisliği seçimine geçilmişti. Her şeyin usul ve hukuk çerçevesinde yapılmasına özen gösterilmiştir. Bunun üzerine Trabzon delegesi Ömer Fevzi Bey, söz alarak kongre delegelerinin birbirlerini tanımadıklarını, bu konuda uzlaşının aranması için reis seçimin ertesi günü bırakılmasının doğru olacağını ifade etmişti. Ömer Fevzi Bey, aslında yukarıda da ifade edildiği gibi askerin kongreye katılmasının bir vesayet göstergesi olacağını, bunun demokratik bir tavır olmayacağını ileri sürüp, özelde de Mustafa Kemal Paşa'nın kongreye katılmasına dolayısıyla da reis seçilmesine karşı olduğunu defaatle ifade etmişti. Bu teklife yine bir başka Trabzon delegesi Servet Bey tarafından cevap verilmiş, teklifin reddedilmesi gerektiğini gerekçeleri ile izah etmiştir. $\mathrm{Bu}$ tartışmaların ardından da ertelenme önerisi reddedilmiş ve seçimlere geçilmişti. $O$ an kongrede hazır bulunduğu anlaşılan 45 delegenin özgür iradesiyle ve 38 kişinin tercihiyle Mustafa Kemal Paşa kongre reisliğine seçilmiş oldu. (Kırzıoğlu, 1993, s. 14; Turan, 1991, s. 208; Goloğlu, 1968, s. 81).

$\mathrm{Bu}$ yeni durum üzerine Kongre Riyaset Divanı için de seçimler yapılmış olması, daha doğrusu her verilecek kararın seçimlerle tayini, çok dikkat çekici bir tavır ve duruş olmuştu. Yapılan seçimlerde Erzurumlu Hoca Raif Efendi ve Trabzonlu İzzet Bey ikinci reisliğe, katipliklere de Erzurumlu Süleyman Necati Bey ve Trabzonlu Abdullah Hasib Efendiler seçilmiştir.

Kongrede çalışmalar bu minval üzere devam ederken bir sorun ortaya çıkmıştı. bu sorun Mustafa Kemal Paşa'nın üniforması ve Yaveran-1 Hazreti Şehriyari kordonu ile yaverleri de askeri kıyafetleri ile toplantı salonuna girmiş olmasıydı. Önceki tartışma konuları dikkate alınırsa böyle bir sorunun olacağı belli olmuştu. Mustafa Kemal Paşa'nın askeri kıyafetle kongreye katılmaması hususunda İbrahim Hamdi Bey (Giresun), Fazlullah Efendi (Sivas) ve Zeki Beylerin (Gümüşhane) hassasiyet gösterdikleri ve Mustafa Kemal Paşa'yı uyardıkları anlaşılmaktadır (Sürmeli, 1997, s. 37). Karabekir Paşa, İstiklal Harbimiz adlı eserinde bu konuyu şöyle zikretmektedir: "Mustafa Kemal Paşa başkan seçiliyor. Riyaset kürsüsüne mirliva üniforması ve padişah kordonuyla çıkması münasebetsiz bir muameleye kendilerini maruz bırakıyor. Gümüşhane delegesi Zeki Bey, başkanlık kürsüsündeki Mustafa Kemal Paşa'ya hitapla: Paşa evvela arkanızdaki elbisenizi ve göğsünüzdeki kordonunuzu çıkarın da, sonra başkanlığa başlayın. Tahakkümden korkuyoruz diyor. Mustafa Kemal Paşa tabii pek müşkül bir vaziyette kalıyor; o akşam üniformayı atmaya mecbur kalıyor.” (Karabekir, 1990, s. 78). ${ }^{5}$

${ }^{5}$ Kadirbeyoğlu Zeki Bey ise hatıralarında bu durumu şöyle izah ediyor: 
Yaşanan bu gerginliğin ardından Mustafa Kemal Paşa itirazları haklı bulmuş olmalı ki salondan ayrılıp sivil elbiselerini giyerek geri dönmüş ve reis seçilmesinden dolayı Divan tarafindan kürsüye davet edilmişti. Paşa, burada uzunca bir konuşma yaparak içeride ve dişarıda yaşanan gelişmeleri değerlendirmiş, içinde bulunulan meselelerden de ancak milli iradeye sarılarak çıkılabileceğinin altını çizerek, saltanata ve hilafete dua ile konuşmasını tamamlamıştır (Kansu, 1988, s. 80-85).

Konuşmanın ardından da Erzurum delegesi Cevat Bey'in teklifi ile kongrenin açılması münasebetiyle başta padişah'a bağlılık telgrafi olmak üzere hükümeti ve vilayetleri gelişmelerle ilgili bilgilendirmek için telgraflar gönderildi. Akabinde de kongrenin sağlıklı çalışabilmesi için tüzük, matbuat, maliye vb. komisyonlar oluşturularak buralarda görev yapacak üyelerin seçimleri tamamlanmıştı (Goloğlu, 1968, s. 82; Turan, 1991, s. 209; Selvi, s. 110; Kırzıoğlu, 1993, s. 26). Kongrenin ilk günü yaşanan tartışmaların benzerleri kongrenin sonuna kadar devam edecektir. İkinci gün Tedkik-i İtimat Encümeni ve Program Encümeni azaları seçilmişti. Cuma günü resmi tatil olması hasebiyle kongre, 26 Temmuz'da toplanmış ve Nizamnamesi Encümeninin oluşturulması çalışmaları yapılmıştır (Eyyüpoğlu, 2009, s. 257-264).

Kongrede asıl tartışmaların 27 Temmuz'da yapılan dördüncü oturumdan itibaren yaşanmaya başlandığı anlaşılmaktadır. Daha önce kongreye sunulan program tartışmaları devam ederken encümenlere seçimler yapılmıştır. $\mathrm{Bu}$ oturumda gündeme gelen Ermeni ve Rumların faaliyetlerine karşı alınacak tedbirler tartışmaya açılmıştı. Bu esnada Amasya'ya gelen Bekir Sami Bey'in Amerikan mandasını kabulünü isteyen telgrafları, mektupları ve Mustafa Kemal Paşa'nın cevabı gündeme gelmiş ve alınacak önlemler tartışma konusu olmuştur. Bu konuda Kazım Karabekir'de şunları yazmaktadır:

"Rauf Bey'in muvacehesinde, Şark Harekâtını bir iki ayda ikmal edebileceğimi Mustafa Kemal Paşa ispat ettim. Ve kongrede katiyen manda veya nazikane tabiriyle muzaheretten bahsetmemelerini rica ettim. Ve Şarkın, İstiklal Harbine fikirleri hazırlanmıştır, dedim. Buna rağmen de (bir devletin müzahareti) lüzumundan bahsetmişler ve sert bir karşılık görmüşlerdir." (Karabekir, 2000, s. 54).

Kongrede hararetli tartışmalar devam ederken İstanbul'da III. Damat Ferit Hükümeti göreve başlamıştı. Kongrenin tutumu ve çalışmaları karşısında Damat Ferit Hükümeti ajanslara demeç vererek toplantıyı yasadışı ilan etmiş, kongrenin Meclis-i Mebusan niteliğinde olduğunu ve bu durumun Anayasaya aykırı olduğu, dolayısıyla da çalışmalara derhal son verilmesini ifade etmiş, valilerden, komutanlardan gereğinin yapılmasını istemişti.

\footnotetext{
"Camekanlı kapı açılır açılmaz bütün ihtişamı ile büyük üniformasıyla kaşıklı, püsküllü apoletleriyle irili ufaklı umum nişanlarıyla ve Yaveran-1 Hazreti Şehriyari kordonu ile arkasında da Yüzbaşı Cevat ve diğer Mülazım Recep Zühtü aynı büyük üniforma ile içeri girmesinler mi! Zavallı millet. Öteden beri şatafat bu darat ve bu debdebenin zebunu değil midir? İsterse olmasın kafasına vurarak oldurur. Mustafa Kemal Paşa bu hareketi ile murahhaslar üzerinde yapacağı tesir çok iyi olarak keşfetmişti. Ve nitekim öyle de çıktı.

...Gayet sert ve haşin bir sada ile; Efendiler oturunuz! Paşa hemen dışarı çıkınız, daha istifanamenizin mürekkebi kurumadan kongre üzerinde bir tesir icra etmek için bu kıyafetle gelmenize çok teessüf ederim. Hemen çıkınız, başka bir elbiseyle geliniz gelirseniz diyerek elimle de kapıyı gösterdi... Yalnız yanımda oturan Rauf Bey: Zeki ne yaptın diyerek, o kudretli elleriyle sol bacağımı öyle bir sıktı ki, tam bir hafta siyah kaldı. Mustafa Kemal Paşa üç dakika süren bu sükutu, rolünü değiştirmek suretiyle bir aktör vaziyeti aldı:

Efendiler şimdi bu dakikada kanaat getirdim ki, bu memleket hiçbir vakit istiklâlini zayi etmeyecek. Bilakis parlak İstikballere mazhar olacaktır. Zira içimizde medeni cesaretini hiçbir kuvvetin eğemeyeceğini ben de iman ettiğim (eliyle beni göstererek) böyle şahıslar oldukça bizler yaşayacağız. Bu bizim hakkımızdır.”( Kadirbeyoğlu Zeki, 2007, s.58-59)
} 
$\mathrm{Bu}$ gelişme kongre gündemine getirilince Gümüşhane delegesi Zeki Bey İstanbul'un kongre çalışmalarını "tezebzüb ve iğtişaş" olarak değerlendiren hükümete cevap verilmesini istemişti. $\mathrm{Bu}$ konuda delegeler bazı beyanatlar sunmuş ve sert tepkiler gösterilmişti. Özellikle Rauf Bey, hükümetin bu tarz açıklamalarının rahatsız edici ve haksız ifadeler olduğunu ve bu sözlerin tekzip edilmesini, kongrenin toplanmasının Anayasaya aykırı olmadığını, asıl kendilerinin anayasaya riayet etmediklerini söyler. Şu ana kadar kongrede en sert muhalefet edenlerden olan Ömer Fevzi Bey, Damat Ferit'in Saderetten çekilmesine teklif edelim dediği zaman Şiran delegesi Hasan Fahri Efendi, "Biz buraya hükümeti devirmeye gelmedik" diyerek sert bir şekilde itiraz etmişti. Bu tarz tartışmalar üzerine kongre, her delegenin kendi adına veya intihab edilecek bir encümen tarafından hazırlanacak metinle protesto edilmesinin uygun olacağ1 yönünde bir karar alır (Kırzıoğlu, 1993, s. 77-79). Böylece mesele halledilmiş olur. Bu minvalde Harbiye Nezareti Erzurum'da toplanan kongre ile ilgili cihet-i askeriye bunlara karşı ne yapıyor? diye sorunca Kazım Karabekir Paşa, "Halk memleketimizi kimseye vermeyiz diye karar alıyor. $\mathrm{Bu}$ haklı teşebbüslerinde bende lazım gelen kolaylıklarda bulunuyorum," diyerek en güzel cevabı vermiş, tavrı ve duruşunu teyit etmişti (Karabekir, 1990, s.80).

Kongre, korku, endişe ve ümit arasında yaşanan gelgitlerle çalışmalarına devam ediyordu. Komisyonlar da çalışmalarına ciddiyetle sürdürüyordu. Nihayetinde kongre en ciddi çalışmayı gündemine aldı. Daha önce oluşturulan Program Encümeni'nden gelen ve ilk taslağı Heyet-i Faale tarafından hazırlanan ve kongre kararlarını teşkil edecek 10 maddelik layiha görüşmelerine geçilmişti (Goloğlu, 1968, s. 88; Selvi, 2000, s. 112). Bu maddeler üzerinde katılımcı delegelerin özgür iradelerini kullanarak her bir madde üzerinde görüşlerini ifade ettikleri görülmüştü. Yukarıda ifade edilen taslak metin görüşülürken Trabzon, Sürmene, Giresun, Tirebolu delegeleri tarafından Adem-i Merkeziyetçi bir alternatif program taslağı kongrenin gündemine sunulmuş ve bu taslak da delegeler tarafindan tartışılmıştır (Goloğlu, 1968, s. 197-200).

Erzurum Kongresi, iki hafta süren çalışmalarda, tartışmalara sebep olan birçok meseleyi karara bağlamışt1. Kongrenin son günü, 13. oturumunda daha önce gündeme gelen Heyet-i Temsiliye'nin seçimlerine sıra gelmişti. Heyetin görev ve yetkileri çokça tartış1lmış ve nihayetinde delegeler özgür iradeleri ile kendi namzetlerini kongre reisliğine sunmuştu. $\mathrm{Bu}$ aşamada Mustafa Kemal Paşa ve Rauf Bey'in heyete seçilmeleri hususunda görüş ayrılıkları olmuştu. Hatta kendi yakın çevresindeki isimlerden Albay Kazım (Dirik), Dr. İbrahim Tali, Binbaşı Hüsrev, Mazhar Müfit ve İbrahim Süreyya Bey'den bu konuda görüşlerini açıkça yazmalarını istemişti. Bunların arasında yalnızca Dr. İbrahim Tali Bey her ikisinin de Heyet'e girmemeleri gerektiğini ifade etmişti (Kansu, 1988, s. 110-112).

Heyet-i Temsiliye'nin seçiminde Erzurum, Sivas, Erzincan ve Trabzon delegeleri kendi namzetlerini teklif etmişlerdi. Erzurum delegeleri Mustafa Kemal Paşa'yı Sivas delegeleri ise Rauf Bey'i kendi listelerinden göstermişti. Yapılan seçimlerde Mustafa Kemal Paşa ve Rauf Bey, Kongre'de hazır bulunanlar 47 delegeden 46'sının oyuyla Heyet-i Temsiliye'ye seçilmişti (Kırzıoğlu, 1993, s. 232-235). Böylece 9 kişilik Heyet i Temsiliye teşekkül ettirilmişti. Seçimlerde dikkat çeken bir husus da şu idi: Kendileri delege olmalarına rağmen kongreye çeşitli sebeplerle gelemeyen Bekir Sami, Hacı Musa ve Sadullah Efendilerin de seçilmiş olmalarıydı. $\mathrm{Bu}$ durumu Şerafettin Turan şöyle izah ediyor: "Bu kabul edilen tüzüğün hükümlerine uymanın yanında, bölgelerinde etkili olan kişileri kurula almak düşüncesinin bir sonucu idi." (Turan, 1991, s. 213). 
Kongre'de genel kurulun beyannameyi kabul etmesiyle misyon da tamamlanmış oldu. Bu beyanname ile Vilayat-1 Şarkiyye Müdafaa-i Hukuk Cemiyeti ile bağlar kesilmiş, Cemiyet Şarkî Anadolu Müdafaa-i Hukuk Cemiyeti adını almıştı. Kongre reisi olarak Mustafa Kemal Paşa: "Tarih bu kongremizi şüphesiz ender ve büyük bir eser olarak kaydedecektir." diyerek katılımcılara teşekkür etmiş, akabinde de Şiran Müftüsü Hasan Efendi'nin duası ile kongre çalışmalarla son vermiştir (Dursunoğlu, 1946, s. 119-120).

\section{Sonuç}

Erzurum Kongresi; Trabzon, Canik dahil olmak üzere tüm Doğu Anadolu'yu kapsayan bölgesel kongre olarak toplanmıştır. Kongre iki hafta boyunca çok önemli çalışmalar yapmış ve kayda değer kararlar almıştır. Kongre şu dikkat çekici sonuçlarla tarihe geçmiştir:

$\checkmark$ Milli irade vurgusu her aşamada ifade edilmiş ve her şeyin üstünde görülmüşsür.

$\checkmark$ Seçim kültürü ve iradeye saygı dikkat çekmiştir.

$\checkmark$ Konular özgürce tartışılmıştır.

$\checkmark$ Kongre boyunca particilik ve siyasetten uzak durulmuştur.

$\checkmark$ Ülkenin bütünlüğü devletin bağımsızlığı sağlam bir şekilde ifade edilmiştir.

$\checkmark$ Nezakete ve usluba dikkat edilmiştir.

$\checkmark$ Delegeler kongrenin üstünde her türlü vesayeti reddetmiştir.

$\checkmark$ Demokrasinin kuralları işletilmiştir.

$\checkmark$ Düşmana karşı daima birlik olunması vurgulanmıştır. 


\section{Kaynakça}

\section{Arşiv}

Türkiye Cumhuriyeti Cumhurbaşkanlığı Devlet Arşivleri Başkanlığı Osmanlı Arşivi(BOA)

Ankara Üniversitesi Türk İnk1lap Tarihi Enstitüsü (TİTE)

\section{Resmi Yayınlar}

TBMM-Zabit Ceridesi, I/1, Ankara, 1981.

Harp Tarihi Vesikaları Dergisi (HTVD).

\section{Gazeteler}

İstiklal Savaşı Gazetesi.

\section{Araştırma Eserler}

\section{Kitaplar}

Akandere, O. (2015). Atatürk'ün seçim yolu ile üstlendiği vazifeler, Ankara.

Akbulut, D. A. (1989). Erzurum Kongresi hakkında belgeler, Erzurum.

Arıburnu, K. (1997). Sivas Kongresi, Samsun'dan Ankara'ya kadar olaylar ve anılarla, Ankara.

Atatürk, K. (1989). Nutuk (1919-1927), Ankara.

Atatürk ile İlgili Arşiv Belgeleri (1911-1921 Tarihleri Arasına Ait 106 Belge (1982), Ankara.

Atatürk, (1970). (Haz.) Salih Omurtak, Hasan Ali Yücel, İhsan Sungu, Enver Ziya Karal, Faik Reşit Unat, Enver Sökmen, Uluğ İğdemir, İstanbul.

Bayar, C. (1972). Bende yazdım, Milli mücadele, VIII, İstanbul.

Baykal, B. S. (969). Erzurum Kongresi ile ilgili belgeler, Ankara.

Cebesoy, A. F. (1993). Milli mücadele hatıralart, İstanbul.

Çil, Y. (2005). Erzurum Kongresine katılan delegeler, Ankara.

Dursunoğlu, C. (1946). Milli mücadelede Erzurum, Ankara.

Eyyüpoğlu, İ. (2009). Osmanlı'dan Cumhuriyet'e bir ittihatçı Kazım Yurdalan (1881/2-1962), Erzurum.

Goloğlu, M. (1968). Erzurum Kongresi, Ankara.

Gökbilgin, M. T. (1959). Milli mücadele başlarken (Mondros Mütarekesinden Sivas Kongresine), C.I, Ankara.

Güneri, S. N. (1999). Hatıra defteri, (Haz.) Ali Birinci, İstanbul.

Kansu, M. M. (1988). Erzurum'dan ölümüne kadar Atatürk'le beraber, I, Ankara.

Karabekir, K. (1990). İstiklal harbimiz, İstanbul: Yüce. 
Karabekir, K. (2000). Paşaların Hesaplaşması (İstiklal Harbine neden girdik, nasıl girdik, nasıl idare ettik?) (Haz. Faruk Özerengin), İstanbul.

Kırzıoğlu, F. (1991). Mustafa Kemal Paşa-Erzurum ilişkileri üzerine belgeler (1919-1920), Ankara.

Kırzıŏglu, F. (1993). Bütünüyle Erzurum Kongresi, II, Ankara.

Lermioğlu, Ö. F. (Haz.). (2007). Kadirbeyoğlu Zeki Bey’in hatıralarl, İstanbul: Sebil.

Onar, M. (1995). Atatürk'ün Kurtuluş Savaşı yazıları, I, Ankara.

Oranlı, Z. (1967). Atatürk'ün şimdiye kadar yayınlanmamış anıları, (Anlatan) Ali Metin, Ankara.

Selvi, H. (2000). Milli mücadele'de Erzurum (1918-1929), Ankara.

Tansel, S. (1991). Mondros 'tan Mudanya'ya kadar, II, İstanbul.

Turan, Ş. (1991). Türk devrim tarihi (İmparatorluğun çöküşünden ulusal direnişe), Ankara.

\section{Makaleler}

(1968). "Bu iradenin yürütülmesine Harbiye Nazırı memurdur.” Mustafa Kemal'in üçüncü ordu müfettişliği’nden azledilmesi belgeleri, Belgelerle Türk Tarihi Dergisi (Dün-Bugün-Yarın), 14.

Kırzıoğlu, F. (1970). Yayınlanmamış belgelerle Erzurum Kongresi’nin ilk günü, Belgelerle Türk Tarihi Dergisi (Dün-Bugün-Yarın), 35.

Sürmeli, S. (1997). Mustafa Kemal Paşa'nın Erzurum Kongresi sırasında üniforma giyme meselesi, Atatürk Üniversitesi Atatürk İlkeleri ve İnklap Tarihi Enstitüsü Dergisi (Mustafa Kemal Atatürk ve Erzurum Özel Sayısi), II(1).

Unat, F. R. (1962). Atatürk'ün askerlikten istifası ve Erzurum'da tevkifi teşebbüsü ile ilgili bazı vesikalar, Tarih Vesikaları, I(1). 